The Progressive Fish-Culturist, Vol. 49, Iss. 4 (Oct. 1987) pp. 312-314.

http://afs.allenpress.com

http://afs.allenpress.com/archive/1548-8640/49/4/pdf/i1548-8640-49-4-312.pdf

Online ISSN: 1548-8640

Print ISSN: 0033-0779

DOI: 10.1577/1548-8640(1987)49<312:AOLOIF>2.0.CO;2

(C) American Fisheries Society 


\section{Application of Liquid Oxytetracycline in Formulated Feeds \\ to Mark and Treat Tiger Muskellunge (Northern Pike $\times$ Muskellunge)}

David H. Wahl and Roy A. Stein

Ohio Cooperative Fish and

Wildlife Research Unit ${ }^{1}$

Department of Zoology, 1735 Neil Avenue

Columbus, Ohio 43210, USA

Abstract. - When added to pelleted diets, liquid oxytetracycline $(500 \mathrm{mg} / \mathrm{kg}$ of fish per day) was effective in marking (after $12 \mathrm{~d}$ ) and disease treatment (after $3 \mathrm{~d}$ ) of tiger muskellunge (the hybrid of northern pike, Esox lucius, and muskellunge, E. masquinongy). Liquid oxytetracycline is more easily applied and costs less than traditional methods for these purposes.

'The unit is sponsored jointly by the U.S. Fish and Wildlife Service, Ohio Department of Natural Resources, and The Ohio State University. 
Tetracycline has been used to mark a variety of fishes, including rainbow trout (Salmo gairdneri), Pacific salmon (Oncorhynchus spp.), Atlantic salmon (Salmo salar), and walleye (Stizostedion vitreum) (Weber and Ridgway 1967; Scidmore and Olson 1969; Trojnar 1973; Odense and Logan 1974). Tetracyclines are deposited in developing bone and fluoresce under ultraviolet light. Dosages for successful marking vary by species and size and have not been quantified for tiger muskellunge (the hybrid of northern pike, Esox lucius, and muskellunge, $E$. masquinongy). Tetracycline antibiotics also are used to treat several bacterial diseases in hatchery fish stocks (Warren 1981), for which low cost and ease of application are im. portant. We describe a simple method to apply liquid oxytetracycline for marking and disease treatment of tiger muskellunge, and we evaluate its effectiveness.

Most commonly, powdered tetracyclines are incorporated into feed pellets during manufacture (Koenings et al. 1986) or the antibiotic is coated on pellets with oil or gelatin at the hatchery. The powder also can be dissolved in water; the food is soaked in this mixture, then dried and crumbled (Trojnar 1973). However, tetracycline is subject to leaching and the change in consistency of the pellet may affect fish feeding and the use of automatic feeders. Alternatively, immersion (Scidmore and Olson 1969), force-feeding of capsules (Weber and Ridgway 1967), and injection have been used to administer tetracycline. These methods of application are either expensive or laborintensive.

In our work, we added veterinary grade liquid oxytetracycline $\mathrm{HCl}$ ( $100 \mathrm{mg}$ active ingredient $/ \mathrm{mL}$ ) to pelleted tiger muskellunge diets at a rate of 500 $\mathrm{mg} / \mathrm{kg}$ of fish per day. At this dosage, the liquid oxtetracycline was quickly absorbed by the pellets, with no apparent change in consistency or texture. This daily dosage was intermediate between those recommended in previous evaluations of marking with oxytetracycline (Weber and Ridgway 1967; Trojnar 1973; Odense and Logan 1974). Glucosamine, a potentiator that enhances tetracycline marking, was added to the liquid oxytetracycline ( $25 \mathrm{mg} / \mathrm{kg}$ of fish per day) before feed treatment (Weber and Ridgway 1967).

To evaluate marking success, tiger muskellunge were first fed treated pellets for $6 \mathrm{~d}$ (Table 1), then they were subsampled and examined for marks under ultraviolet light (Odense and Logan 1974). After $6 \mathrm{~d}$, marks were visible in most, but not all, fish examined. To avoid any reduced feeding be-
TABLE 1.-Success of marking young-of-year tiger muskellunge with liquid oxytetracycline $(500 \mathrm{mg} / \mathrm{kg}$ of fish per day) for one or two 6-d treatments, the latter with a $7-d$ interval between treatments.

\begin{tabular}{ccccc}
\hline $\begin{array}{c}\text { Treatment } \\
\text { duration (d) }\end{array}$ & $\begin{array}{c}\text { Number of } \\
\text { fsh treated }\end{array}$ & $\begin{array}{c}\text { Mean fish } \\
\text { weight }(\mathrm{g})\end{array}$ & $\begin{array}{c}\text { Number } \\
\text { examined }\end{array}$ & $\begin{array}{c}\text { Percent } \\
\text { marked }\end{array}$ \\
\hline 6 & 1,150 & 12 & 10 & 80 \\
$6+6$ & 1,150 & 12 & 20 & 100 \\
6 & 1,000 & 5 & 20 & 90 \\
$6+6$ & 1,000 & 5 & 20 & 100 \\
$6+6$ & 1,600 & 13 & 20 & 100 \\
$6+6$ & 3,000 & 29 & 20 & 100 \\
\hline
\end{tabular}

havior that can result from extended treatment with tetracycline, we fed fish untreated pellets for 1 week before giving them treated pellets again for an additional $6 \mathrm{~d}$. In four trials, fluorescence was visible in all tiger muskellunge examined for marks after the second 6-d treatment (Table 1).

Oxytetracycline proved an effective method for marking tiger muskellunge. Length of treatment (12 d) and total dosages of tetracycline $(6 \mathrm{~g} / \mathrm{kg})$ required for complete marking were higher than those reported by Weber and Ridgway (1967) for Pacific salmon (4-8 d; $1-2 \mathrm{~g} / \mathrm{kg}$ ). Calcium content of the diet, fish size, and species may affect efficiency of tetracycline absorption and should be considered for each species application.

Two additional trials evaluated the effectiveness of liquid oxytetracycline in treating columnaris (Flexibacter columnaris), a commonly occurring bacterial infection in tiger muskellunge. Two groups of infected fish $(N=1,000$ and 3,000$)$ were successfully treated after feeding for $3 \mathrm{~d}$ at $500 \mathrm{mg} / \mathrm{kg}$ per day. Disease treatment did not require the extended feeding period necessary to mark the fish.

Liquid oxytetracycline provides a simple and inexpensive method for marking or disease treatment in a variety of hatchery-reared fishes. Current cost per gram of active oxytetracycline is similar for liquid (US\$0.18/g) and powdered ( $\$ 0.21 /$ g) forms. Unlike traditional forms of application, liquid oxytetracycline requires no special procedures and mixes easily with pelleted diets.

Acknowledgments. - We thank T. Nagel (London Fish Farm) and P. Keyes (Hebron Fish Farm) of the Ohio Division of Wildlife and M. Mather (Aquatic Ecology Laboratory, The Ohio State University) for providing tiger muskellunge. $D$. Bryson, J. Farwick, D. Imhoff, and K. Bruner provided technical assistance. F. J. Margraf and two anonymous reviewers improved the manuscript. This research was supported in part by funds from 
the Federal Aid in Fish Restoration Act, Project F.57-R.

\section{References}

Koenings, J. P., J. Lipton, and P. McKay. 1986. Quantitative determination of oxytetracycline uptake and release by juvenile sockeye salmon. Transactions of the American Fisheries Society 115:621-629.

Odense, P. H., and V. H. Logan. 1974. Marking Atlantic salmon with oxytetracycline. Journal of the Fisheries Research Board of Canada 31:348-350.
Scidmore, W. J., and D. E. Olson. 1969. Marking walleye fingerlings with oxytetracycline antibiotic. Progressive Fish-Culturist 31:213-216.

Trojnar, J. R. 1973. Marking rainbow trout fry with tetracycline. Progressive Fish-Culturist 35:52-54.

Warren, J. W. 1981. Diseases of hatchery fish. U.S. Fish and Wildlife Service, Region 3, Twin Cities, Minnesota.

Weber, D. D., and G. J. Ridgway. 1967. Marking Pacific salmon with tetracycline antibiotics. Journal of the Fisheries Research Board of Canada 24:849 865. 